\title{
DETERMINASI PENGUNGKAPAN SYARIAH TERHADAP STANDAR AAOIFI : STUDI TERHADAP DAFTAR EFEK SYARIAH DI INDONESIA
}

\author{
Ahmad Dzakiyuddin \\ Program Studi Magister Akuntansi, Fakultas Ekonomi dan Bisnis, Universitas \\ Sebelas Maret Email : ahmdzay9@gmail.com
}

\begin{abstract}
ABSTRAK
Tujuan dari penelitian ini adalah untuk mengetahui pengaruh kepatuhan terhadap prinsip syariah, rasio leverage, rasio pengakuan pendapatan dan skor tata kelola islam pada tingkat pengungkapan. Kepatuhan terhadap prinsip syariah diukur sesuai dengan Peraturan Badan Pengawas dan Pasar Modal (BAPEPAM) dan Lembaga Keuangan mengenai Kriteria Penerbitan Daftar Efek Syariah. Rasio leverage dan rasio pengakuan pendapatan ditentukan dengan menggunakan kriteria yang ditetapkan oleh DSN-MUI dan tertulis pada Peraturan OJK tentang Kriteria dan Penerbitan Daftar Efek Syariah. Sementara Skor Tata Pemerintahan Islam merupakan proksi dari karakteristik Dewan Pengawas Syariah (DPS). Tingkat pengungkapan diukur dengan merumuskan indeks pengungkapan berdasarkan Teori Perusahaan Syariah. Sampel dalam penelitian ini adalah 343 Daftar Efek Syariah di Indonesia pada tahun 2018. Hasil penelitian menunjukkan bahwa semua variabel independen signifikan terhadap tingkat pengungkapan.

Kata-kata kunci : Pengungkapan Syariah, Kepatuhan, Leverage, PengakuanPendapatan, Tata Kelola Islami

ABSTRACT

The purpose of this study is to determine the impact of compliance with sharia principles, leverage ratio, revenue recognition ratio and islamic governance score on the disclosure level. Compliance with sharia principles is measured in accordance with the capital market and Financial Institution Supervisory Agency Regulations concerning Criteria for Issuance of List of Sharia Securities. The leverage ratio and revenue recognition ratio are determined using the criteria set by DSN-MUI and written on OJK regulations concerning Criteria and Issuance of List of Sharia Securities. Meanwhile the Islamic Governance Score is a proxy for the characteristics of the Sharia Supervisory Board (DPS). Level of disclosure measured by formulating a disclosure index based on Sharia Company Theory. The sample in this study was 343 Lists of Sharia Securities in Indonesia in 2018. The results of the study indicate that all independent variables are significant for the disclosure level.
\end{abstract}

Keywords: Sharia Disclosure, Compliance, Leverage, Revenue Recognition, Islamic Governance 


\section{PENDAHULUAN}

Entitas syariah memiliki tanggung jawab atas visi syariah pada setiap kegiatan operasional mereka dan tercermin dalam laporan keuangan (Budiono, 2017). Pengungkapan dalam laporan tahunan perusahaan merepresentasikan bahwa seluruh aktivitas perusahaan sesuai dengan prinsip syariah (Che Azmi, 2016). Entitas syariah yang mampu mengelola laporan keuangannya dengan baik dapat meningkatkan nilai dan reputasi mereka (Alessandri dan Westcott, 2001). Kepercayaan ini tidak hanya bagi investor muslim saja akan tetapi juga non-muslim dan semua investor yang memiliki ketertarikan untuk melakukan investasi di perusahaan syariah.

Entitas syariah saat ini berkembang dengan pesat di dunia dan mengalami perkembangan 10-15\% tiap tahunnya (Sole, 2007). Malik dan Mustafa (2011) menyebutkan bahwa lebih dari 475 entitas syariah tersebar di 75 negara dengan operasional sesuai dengan prinsip syariah. Perkembangan ini menunjukkan bahwa sistem syariah mampu beradaptasi dengan sistem konvensional yang telah menguasai kehidupan masyarakat (Muhammad, 2015).

Entitas syariah di Indonesiadapat diakses melalui Dafter Efek Syariah (DES) yangtelah mulai diterbitkan pada tahun 2007 (Khoiruddin dan Faizati, 2014). DES merupakan kumpulanefek yang tidak bertentangan dengan prinsip-prinsipsyariah di pasar modal. DES tersebutmerupakan panduan investasi bagi reksadanasyariah dalam menempatkan dana kelolaannya,serta dapat juga dipergunakan oleh investoryang mempunyai keinginan untuk berinvestasi pada portofolio efek syariah.

Perkembangan entitas syariah diikuti dengan pembentukan Standar Akuntansi Syariah oleh Ikatan Akuntan Indonesia. Standar Akuntansi Syariah merupakan Pernyataan Standar Akuntansi Keuangan (PSAK) Syariah yang ditujukan untuk entitas yang melakukan transaksi syariah baik entitas lembaga syariah maupun lembaga non syariah. Harahap (2001) menyebutkan bahwa pembentukan PSAK syariah berkiblat pada salah satu organisasi Islam di Timur Tengah yaitu Accounting and Auditing Organization of Islamic Financial Institution (AAOIFI). Standar AAOIFI merupakan standar akuntansi syariah internasional yang berfungsi untuk penyeragaman perlakuan akuntansi entitas syariah global (AAOIFI, 2015). 
Penelitian sebelumnya yang menguji kesesuaian standar laporan keuangan syariah dengan AAOIFI dilakukan oleh Ullah (2013) dengan sampel 30 perbankan syariah yang masuk dalam kategori pada Bursa Efek Syariah Dhaka (DSE). Penelitian ini menguji apakah terdapat hubungan antara pelaporan Corporate Social Responsibility (CSR) dengan karakteristik perbankan syariah. Hasil dari penelitian mengungkapkan bahwa tingkat rata-rata pelaporan CSR dibawah 50\% dari item laporan tahunan. Penelitian ini tidak menemukan pengaruh yang signifikan dari karakteristik sampel perbankan yang dipilih dengan tingkat pelaporan CSR.

Ahmed dan Khatun (2014) melakukan penelitian pada perbankan syariah di Bangladesh dengan menggunakan indikator karakteristik perusahaan dan karakteristik Dewan Pengawas Syariah (DPS). Penelitian tersebut menguji tingkat kepatuhan 17 perbankan syariah swasta dan kesesuaian sistem tata kelola syariah menurut standar AAOIFI. Hasil penelitian menunjukkan bahwa tidak ada perbankan syariah di Bangladesh yang sepenuhnya mematuhi sistem tata kelola syariah sesuai standar AAOIFI. Hal ini dikarenakan komite pengawas syariah terdiri dari luar (eksternal) dan internal perbankan. Penunjukkan pengawas syariah dari internal perbankan syariah merupakan ketidaksesuaian dan penyimpangan terhadap standar AAOIFI.

Penelitian Halaby (2016) menguji tingkat kesesuaian standar AAOIFI perbankan syariah di negara Bahrain, Jordan dan Qatar dengan indikator karakteristik perusahaan, karakteristik DPS, penyajian laporan keuangan, tata kelola perusahaan (CG) dan Corporate Social Responsibility (CSR). Sementara itu penelitian Al-Sulaiti dkk (2018) yang memperbandingkan perbankan syariah di Bahrain dan Qatar menggunakan indeks pengungkapan syariah yang mencakup tiga standar murabahah, musyarakah dan mudharabah.

Dalam penelitian ini penulis akan melakukan investigasi kesesuaian pengungkapan syariah yang dilakukan oleh perusahaan yang masuk dalam Daftar Efek Syariah (DES) tahun 2018 dengan standar AAOIFI. Penelitian ini menggunakan empat indikator syariah DES yang dirumuskan oleh lembaga Otoritas Jasa Keuangan (OJK) berupa kesesuaian dengan prinsip syariah, rasio leverage, rasio revenue recognition dan skor Islamic Governance. Penulis menambahkan variabel skor Islamic 
Governance (IG)dikarenakan dalam transaksi keuangan tentu memiliki resiko yang tinggi dengan harapan mendapatkan return yang tinggi. Oleh karena itu dalam hal ini penting menerapkan tata kelola perusahaan (Governance) sesuai dengan prinsip syariah (Hadi, 2017).

\section{METODE PENELITIAN}

1. Subjek penelitian

Populasi dalam penelitian ini adalah seluruh daftar efek syariah di Indonesia yang berjumlah 368 unit efek dengan tahun penelitian 2018.

2. Jenis data

Jenis data yang digunakan dalam penelitian ini adalah digunakan dalam penelitian ini adalah data sekunder yang diperoleh dari annual report daftar efek syariah di Indonesia periode 2018. Data sekunder merupakan sumber data penelitian yang diperoleh dari peneliti melalui media perantara atau data yang diperoleh dan dicatat oleh pihak lain yang berwenang (Indriantoro dan Supono dalam Purwanti, 2006).

3. Teknik pengambilan sampel

Penelitian ini menggunakan metode purposive sampling dalam pemilihan sampel. Kriteria yang dijadikan sampel dalam penelitian ini adalah daftar efek syariah yang menerbitkan annual report tahun 2018 yang dapat diakses dari website masing-masing efek.

a. Definisi operasional variabel penelitian

1) Variabel Dependen

Variabel dependen merupakan variabel yang dipengaruhi oleh variabel lain. Variabel dependen dalam penelitian ini adalah tingkat pengungkapan syariah pada laporan tahunan efek syariah. Tingkat pengungkapan syariah dalam penelitian ini adalah Peraturan Badan Pengawas Pasar Modal dan Lembaga Keuangan Nomor KEP-208/BL/2012 tentang Kriteria Penerbitan Daftar Efek Syariah.

2) Variabel Independen

Variabel Independen merupakan variabel bebas yang tidak 
terikat dengan variabel lainya. Dalam penelitian ini variabel independen meliputi indikator syariah Daftar Efek Syariah yang dirumuskan oleh OJK berupa :

a) Kesesuaian dengan prinsip syariah. Perhitungan variabel kesesuaian dengan prinsip syariah diukur dengan 3 (tiga) ketentuan kepatuhan syariah. Setiap komponen diberi skor 1 bila ada dan 0 bila tidak memiliki syarat-syarat, kemudian dirata-rata untuk mendapatkan nilai kepatuhan syariah tersebut.

b) Rasio leverage. Perhitungan variabel rasio leverage diukur dengan total utang yang berbasis bunga dibandingkan dengan total aset efek syariah tidak lebih dari $45 \%$. Setiap komponen diberi skor 1 bila sesuai dengan ketentuan dan 0 bila tidak memenuhi ketentuan tersebut.

c) Rasio revenue recognition. Perhitungan variabel rasio revenue recognition diukur dengan total pendapatan bunga dan pendapatan tidak halal lainnyadibandingkan dengan total pendapatan usaha (revenue) danpendapatan lain-lain tidak lebih dari 10\%. Setiap komponen diberi skor 1 bila sesuai dengan ketentuan dan 0 bila tidak memenuhi ketentuan tersebut.

d) Islamic Governance Score. Perhitungan variabel islamic governance score dalam penelitian ini ditentukan dengan menggunakan content analysis terhadap karakteristik DPS dengan melakukan checklist pada setiap item yang meliputi: keberadaan DPS, jumlah DPS, jumlah rapat, latar belakang pendidikan serta pengalaman dan reputasi dengan ketentuan sebagai berikut:

1) Keberadaan DPS = jika ada diberi skor 1, jika tidak ada maka 0 .

2) Jumlah DPS = jika sama dengan atau lebih dari dua diberi skor 1 , jika kurang maka 0.

3) Jumlah rapat = jika sama dengan atau lebih dari enam kali maka diberi skor 1, jika kurang maka 0. 
4) Latar belakang pendidikan = jika DPS memiliki pendidikan S2/ S3 maka diberi skor 1, jika tidak maka 0.

5) Pengalaman dan reputasi = DPS yang memiliki pengalaman di institusi atau lembaga lain diberi skor 1, sedangkan yang tidak mempunyai pengalaman maka diberi skor 0 .

b. Metode analisis data

Data yang dikumpulkan di dalam penelitian ini diolah kemudian dianalisis dengan alat statistik sebagai berikut:

1) Uji Statistik Deskriptif

Statistik deskriptif memberikan gambaran atau deskripsi suatu data sehingga menjadi sebuah informasi yang lebih jelas dan mudah untuk dimengerti, yang dilihat dari nilai rata-rata (mean), median, modus, standar deviasi, nilai maksimum, dan nilai minimum (Ghozali, 2007).

2) Uji Hipotesis

a) Uji Regresi Linear Berganda. Uji regresi linear berganda dalam penelitian ini adalah untuk mengetahui bagaimana variabel kesesuaian dengan prinsip syariah, rasio leverage, rasio revenue recognition dan islamic governance score berpengaruh terhadap tingkat pengungkapan.

b) Model regresi yang dikembangkan untuk menguji hipotesis-hipotesis dalam penelitian ini dirumuskan sebagai berikut:

\section{Discl $=\beta 0+\beta 1 \mathrm{KePS}+\beta 2 \mathrm{LEV}+\beta 3 \mathrm{REV}+\beta 4 \mathrm{IGS}$}

Keterangan :

Discl $=$ Tingkat Pengungkapan

B0 = Intercept

$ß 1-ß 4=$ Koefisien Regresi

KePS = Kesesuaian dengan Prinsip Syariah

LEV = Rasio Leverage

REV = Rasio Revenue Recognition

IGS = Islamic Governance Score 


$$
\text { e } \quad=\text { error }
$$

4. Uji Koefisien Determinasi (R2)

Pengujian ini bertujuan untuk menunjukan apakah semua variabel independen yang dimasukan dalam model memiliki pengaruh secara bersama-sama terhadap variabel dependen. Ketentuan penerimaan dan penolakan hipotesis sebagai berikut:

a. Jika nilai signifikansi $\mathrm{f}>0,05$ maka hipotesis diterima (koefisien regresi tidak signifikan). Ini berarti bahwa secara simultan keenam variabel independen tidak mempunyai pengaruh yang signifikan terhadap variabel dependen.

b. Jika nilai signifikansi $\mathrm{f} \leq 0,05$ maka hipotesis ditolak (koefisien regresi signifikan). Ini berarti secara simultan keenam variabel independen mempunyai pengaruh yang signifikan terhadap variabel dependen.

c. Uji Signifikansi Parameter Individual (Uji t)

1. Tujuan dari uji $\mathrm{t}$ adalah membandingkan rata-rata dua grup yang tidak berhubungan satu dengan yang lain, apakah kedua grup tersebut mempunyai nilai rata-rata yang sama ataukah tidak sama secara signifikan (Ghozali, 2011). Uji t dilakukan untuk memeriksa lebih dalam manakah diantara empat variabel independen yang berpengaruh signifikan terhadap pengungkapan. Pengujian dilakukan dengan menggunakan significance level 0,05 ( $\alpha=5 \%)$. Penerimaan dan penolakan hipotesis dilakukan dengan kriteria sebagai berikut:

2) Jika nilai signifikansi $t>0,05$ maka hipotesis ditolak (koefisien regresi tidak signifikan). Ini berarti bahwa secara parsial variabel independen tidak mempunyai pengaruh yang signifikan terhadap variabel dependen.

3) Jika nilai signifikansi $\mathrm{t} \leq$ 0,05 maka hipotesis diterima (koefisien regresi signifikan). Ini berarti secara parsial variabel independen mempunyai pengaruh yang signifikan terhadap variabel dependen. 


\section{HASIL DAN PEMBAHASAN}

\section{Pengungkapan Syariah}

Pengukuran pengungkapan syariah dalam hal ini penulis mengkombinasikan standar dari Timur Tengah (Internasional) dan standar Indonesia. Adapun standar Timur Tengah yang diterbitkan oleh AAOIFI yaitu standar pengungkapan pelaporan keuangan Islamic Reporting Index dan dari Indonesia adalah peraturan Otoritas Jasa Keuangan mengenai syarat perusahaan yang masuk dalam kategori Daftar Efek Syariah berupa kesesuaian dengan prinsip syariah, rasio leverage, revenue recognition dan skor Islamic Governance.

Jenis informasi dari pengungkapan syariah sesuai dengan standar AAOIFI yang tercermin dalam laporan keuangan menurut Muhammad (2015) adalah :

a. Informasi tentang kepatuhan lembaga syariah terhadap ketentuan syariah serta tujuan-tujuan yang telah disusun dan informasi yang menyajikan pemisahan pendapatan dan pengeluaran dari sumber dana yang dilarang syariah, dmana hal tersebut bisa terjadi di luar kontrol manajemen.

b. Informasi tentang sumber daya ekonomi lembaga syariah dan kewajiban-kewajiban yang terkait, dampak transaksi-transaksi tersebut, kejadian-kejadian lain dan keadaan sumber daya entitas beserta kewajiban yang ditanggung. Informasi ini diarahkan secara prinsip pada upaya membantu proses evaluasi kecukupan permodalan lembaga syariah untuk menyerap kerugian dan risiko bisnis, pengukuran risiko yang terdapat dalam investasinya dan evaluasi tingkat likuiditas aset dan persyaratan likuiditas yang sesuai dengan kewajibannya.

c. Informasi untuk membantu penghitungan kewajiban zakat dari dana depositor lembaga syariah serta tujuan zakat akan didistribusikan.

d. Informasi yang membantu memperkirakan arus kas yang bisa direalisasikan dari pihak-pihak yang berhubungan dengan lembaga syariah, waktu serta risiko yang terkait dengan proses realisasi tersebut. 
e. Informasi untuk membantu dalam mengevaluasi pemenuhan kewajiban lembaga syariah untuk menjaga dana nasabah dan untuk menginvestasikan dana tersebut pada tingkat keuntungan yang wajar dan tingkat keuntungan yang layak bagi pemilik modal dan pemegang rekening investasi.

f. Informasi tentang pemenuhan pertanggungjawaban sosial lembaga syariah.

\section{Standar AAOIFI}

AAOIFI merupakan lembaga internasional yang mengembangkan standar akuntansi, audit, governance dan etika terkait dengan lembaga keuangan syariah dengan memperhatikan kepatuhan terhadap prinsip syariah dan merupakan salah satu rujukan dalam menyusun standar akuntansi (Ramadhani, 2016).

Standar AAOIFI disusun oleh organisasi nirlaba internasional yang memiliki kompetensi untuk menyusun standar-standar akuntansi keuangan dan auditing untuk Lembaga Keuangan Syariah di dunia. Menurut Muhammad (2015) organisasi nirlaba ini memiliki tujuan antara lain :

a. Mengembangkan pemikiran akuntansi dan auditing yang relevan dengan lembaga keuangan

b. Menyamakan pemikiran di bidang akuntansi dan auditing yang relevan bagi lembaga keuangan dan penerapannya melalui pelatihan, seminar, publikasi jurnal yang merupakan hasil riset

c. Menyajikan, mengumumkan dan menginterpretasikan standar-standar akuntansi dan auditing bagi lembaga-lembaga keuangan syariah

d. Mereview dan mengamandemen standar-standar akuntansi dan auditing bagi lembaga-lembaga keuangan syariah.

AAOIFI menyusun tujuan-tujuan tersebut disesuaikan dengan ketentuan syariah Islam yang mencerminkan sebuah sistem yang komprehensif bagi semua aspek kehidupan manusia dan diselaraskan dengan lingkungan efek atau lembaga keuangan syariah.

Standar AAOIFI memberikan gambaran akuntansi yang sangat kental karena tertulis jelas pengungkapan tersebut untuk pelaporan keuangan. 
Triyuwono (2012) dalam Septyan (2018) menyebutkan bahwa akuntansi adalah disiplin dan praktik yang dibentuk dan membentuk lingkungannya. Pernyataan tersebut memberikan makna bahwa akuntansi syariah dibentuk dari entitas syariah yang membentuk output bernafaskan Islami yang seimbang tidak hanya pada pelaporan keuangan saja tetapi juga pada kepedulian sosial.

3. Pengembangan Hipotesis

a. Hubungan kesesuaian dengan prinsip syariah terhadap tingkat pengungkapan

Kesesuaian dengan prinsip syariah dalam hal ini merupakan fungsi kepatuhan syariah di lembaga keuangan syariah. Fungsi kepatuhan merupakan tindakan dan langkah yang bersifat ex-ante (preventif) untuk memastikan kebijakan, ketentuan, sistem dan prosedur serta kegiatan usaha yang dilakukan oleh lembaga keuangan syariah sesuai dengan ketentuan Otoritas Jasa Keuangan (OJK), fatwa DSN, peraturan perundang-undangan pemerintah yang berlaku dan penetapan hukum yang telah ditetapkan standar internasional Islamic Financial Service Board (IFSB) dan AAOIFI (Sukardi, 2012).

Kepatuhan syariah merupakan manifestasi pemenuhan seluruh prinsip syariah dalam lembaga yang memiliki wujud karakteristik, integritas dan kredibilitas lembaga syariah (Peraturan Bank Indonesia, 2011). Kepatuhan syariah dalam hal ini adalah sesuai dengan Peraturan Badan Pengawas Pasar Modal dan Lembaga Keuangan Nomor KEP-208/BL/2012 tentang Kriteria Penerbitan Daftar Efek Syariah adalah :

1) Perusahaan tidak melakukan kegiatan usaha yang mengandung unsur perjudian (maisir), ketidakpastian (gharar) dan berbasis bunga.

2) Perusahaan tidak memproduksi, mendistribusikan, memperdagangkan atau menyediakan barang atau jasa yang haram secara dzatnya (haram li-dzatihi) atau barang dan jasa yang haram bukan secara dzatnya (haram li-ghoirihi) yang ditetapkan oleh DSN-MUI. 
3) Perusahaan tidak melakukan transaksi yang mengandung unsur suap (risywah).

Di Indonesia, elemen yang memiliki otoritas dan wewenang dalam melakukan pengawasan terhadap kepatuhan syariah adalah Dewan Pengawas Syariah (DPS). DPS merupakan kepanjangan tangan DSN-MUI yang memiliki fungsi sebagai pemantau atas kinerja efek syariah. DPS terdiri dari pakar syariah yang mengawasi aktivitas dan operasional institusi finansial untuk memastikan kepatuhan terhadap prinsip syariah. Peneliti mengambil contoh di Indonesia berupa DPS dari DSN-MUI yang merupakan salah satu pihak yang merumuskan PSAK syariah dengan kiblat dari standar yang diterbitkan AAOIFI (Septyan, 2018). Memperkuat hal ini, Ardian dan Adityawarman (2015) menyatakan bahwa kepatuhan terhadap prinsip syariah akan memiliki pengaruh pada pengungkapan yang dilakukan oleh DPS dalam penyusunan laporan tahunan karena hal ini berhubungan dengan informasi yang akan diberikan dalam laporan tahunan lembaga keuangan syariah tersebut.

Berdasarkan pernyataan di atas dengan didukung penelitian terdahulu maka terbentuklah hipotesa :

H1 : Kesesuaian dengan prinsip syariah berpengaruh positif terhadap tingkat pengungkapan.

\section{b. Hubungan rasio leverageterhadap tingkat pengungkapan}

Rasio leverage dalam hal ini adalah total utang yang berbasis bunga dibandingkan dengan total aset lembaga keuangan syariah tidak lebih dari $45 \%$. Rasio ini merupakan kriteriayang ditetapkan oleh DSN-MUI dengan kiblat perumusan standar PSAK dari standar yang diterbitkan oleh AAOIFI (Septyan, 2018). Kriteria tersebut tertulis pada peraturan OJK Nomor 35/POJK.04/2017 tentang Kriteria dan Penerbitan Daftar Efek Syariah. Dengan kriteria tersebut membuat struktur modal menjadi khas pada perusahaan yang terdaftar di DES. Kriteria ini diharapkan mampu meningkatkan jumlah investor di lembaga keuangan syariah (Khoiruddin dan Faizati, 2014) dikarenakan prinsip syariah yang tercermin dalam rasio leverage tersebut. 
Berdasarkan pernyataan di atas dengan didukung penelitian terdahulu maka terbentuklah hipotesa :

H2: Rasio leverage berpengaruh positif terhadap tingkat pengungkapan.

c. Hubungan rasio revenue recognition terhadap tingkat pengungkapan

Rasio revenue recognition dalam hal ini adalah total pendapatan bunga dan pendapatan tidak halal lainnyadibandingkan dengan total pendapatan usaha (revenue) danpendapatan lain-lain tidak lebih dari 10\%. Rasio ini juga merupakan kriteria yang ditetapkan oleh DSN-MUI dengan kiblat perumusan standar PSAK dari standar yang diterbitkan oleh AAOIFI (Septyan, 2018). Kriteria tersebut tertulis pada peraturan OJK Nomor 35/POJK.04/2017 tentang Kriteria dan Penerbitan Daftar Efek Syariah. Dengan kriteria tersebut membuat struktur pendapatan menjadi khas pada perusahaan yang terdaftar di DES. Batasan jumlah pendapatan non-halal 10\% merupakan penentu penilaian dari syariahnya efek tersebut (Baharudin, 2015). Pengungkapan rasio revenue recognition merupakan bentuk transparansi dan akuntabilitas kepada pemilik modal atas dana-dana yang diinvestasikan (Rostiani dan Sukanta, 2018).

Berdasarkan pernyataan di atas dengan didukung penelitian terdahulu maka terbentuklah hipotesa :

H3 : Rasio Revenue Recognition berpengaruh positif terhadap tingkat pengungkapan.

d.HubunganIslamic Governance Scoreterhadap tingkat pengungkapan

Nabilah dkk (2018) menyebutkan bahwa Islamic Governance Score merupakan proksi dari karakteristik Dewan Pengawas Syariah (DPS). AAOIFI merekomendasikan bahwa anggota yang menduduki jabatan DPS memiliki latar belakang pendidikan akuntansi dan memiliki background yang berbeda dari ekonom dan bankir yang memiliki hubungan dengan dunia perbankan (Septyan, 2018). AAOIFI juga mensyaratkan DPS melaporkan ketaatan efek syariah terhadap syariah. Menurut Peraturan Otoritas Jasa Keuangan (POJK) No. 30/POJK.05/2014 tentang Tata Kelola Perusahaan yang Baik bagi Perusahaan Pembiayaan menyebutkan bahwa "Dewan Pengawas Syariah merupakan bagian dari organ perusahaan yang mempunyai 
tugas dan fungsi pengawasan terhadap penyelenggaraan kegiatan perusahaan agar sesuai dengan prinsip syariah". Pada peraturan tersebut di pasal 40 juga menjelaskan bahwa DPS wajib menyelenggarakan rapat DPS secara berkala paling sedikit 6 (enam) kali dalam 1 (satu) tahun.

Informasi Islamic Governance yang diungkapkan oleh perusahaan syariah masih belum memiliki pengaruh yang signifikan bagi investor dikarenakan kualitas pengungkapan yang masih sangat rendah (Retno, 2012). Namun dalam penelitian Rosiana dkk (2015) di 10 lembaga keuangan syariah di Indonesia menunjukkan bahwa Islamic Governance Score memiliki pengaruh terhadap kualitas pengungkapan dengan catatan beberapa perusahaan justru mengurangi jumlah DPS mereka dalam 3 tahun terakhir periode penilitian.

Berdasarkan pernyataan di atas dengan didukung penelitian terdahulu maka terbentuklah hipotesa :

H4 : Islamic Governance Score berpengaruh positif terhadap tingkat pengungkapan.

\section{Gambaran Objek Penelitian}

Hasil dari seleksi berdasarkan kriteria yang telah ditetapkan pada bab 3, diperoleh jumlah sample sebanyak 343 daftar efek syariah yang memenuhi kriteria. Prosedur pengambilan sampel disajikan pada tabel 1 berikut ini:

Tabel 1: Daftar Efek Syariah 2018 (Berdasarkan Ketersediaan Laporan Keuangan di BEI)

\begin{tabular}{llccc}
\hline No. & \multicolumn{1}{c}{ Kategori } & Jumlah & Tersedia & $\begin{array}{c}\text { Tidak } \\
\text { Tersedia }\end{array}$ \\
\hline 1. & Pertanian & 11 & 8 & 3 \\
\hline 2. & Pertambangan & 31 & 30 & 1 \\
\hline 3. & $\begin{array}{l}\text { Industri dasar dan } \\
\text { kimia }\end{array}$ & 55 & 51 & 4 \\
\hline 4. & Aneka industri & 28 & 24 & 4 \\
\hline 5. & $\begin{array}{l}\text { Industri barang } \\
\text { konsumsi }\end{array}$ & 35 & 34 & 1 \\
\hline 6. & $\begin{array}{l}\text { Properti, Real estate } \\
\text { dan }\end{array}$ & 56 & 55 & 1 \\
\hline
\end{tabular}




\begin{tabular}{llccc}
\hline bangunan & & & \\
\hline 7. & $\begin{array}{l}\text { Infrastruktur, Utilitas } \\
\text { dan Transportasi }\end{array}$ & 45 & 43 & 2 \\
\hline 8. & Keuangan & 5 & 5 & - \\
\hline 9. & $\begin{array}{l}\text { Perdagangan, Jasa } \\
\text { dan Investasi }\end{array}$ & 102 & 93 & 9 \\
\hline Jumlah Keseluruhan & 368 & 343 & 25 \\
\hline
\end{tabular}

Sumber : data diolah oleh peneliti (Laporan Keuangan di BEI)

5. Statistik Deskriptif

Tabel 2 : Statistik Deskriptif Variabel Dependen dan Independen

\begin{tabular}{llllll}
\hline & Y & X1 & X2 & X3 & X4 \\
Mean & 0.719315 & 0.982507 & 0.985423 & 0.311953 & 0.597376 \\
Median & 0.675000 & 1.000000 & 1.000000 & 0.000000 & 0.600000 \\
Maximum & 0.975000 & 1.000000 & 1.000000 & 1.000000 & 1.000000 \\
Minimum & 0.300000 & 0.000000 & 0.000000 & 0.000000 & 0.100000 \\
Std. Dev. & 0.122312 & 0.131290 & 0.120028 & 0.463968 & 0.187533 \\
Skewness & 0.251966 & -7.361010 & -8.100296 & 0.811786 & -0.087163 \\
Kurtosis & 3.072849 & 55.18447 & 66.61479 & 1.658997 & 2.472828 \\
& & & & & \\
Jarque-Bera & 3.705187 & 42016.88 & 61587.09 & 63.37322 & 4.406124 \\
Probability & 0.156830 & 0.000000 & 0.000000 & 0.000000 & 0.110464 \\
& & & & & \\
Sum & 246.7250 & 337.0000 & 338.0000 & 107.0000 & 204.9000 \\
Sum Sq. Dev. & 5.116414 & 5.895044 & 4.927114 & 73.62099 & 12.02764 \\
Observations & 343 & 343 & 343 & 343 & 343 \\
\hline
\end{tabular}

Sumber : hasil olah data Eviews 9.

Secara keseluruhan, rata-rata pengungkapan efek syariah (Y) dari 343 efek tersebut sebesar 71,9 point dari seluruh indeks pengungkapan. Untuk 4 (empat) variabel dengan jumlah sampel yang besar, variabel kesesuaian dengan prinsip syariah (X1), rasio leverage (X2) dan rasio revenue recognition $(\mathrm{X} 3)$ merupakan variabel yang menyandang predikat pengungkapan dengan score maksimal dan score minimal.Berdasarkan tabel diatas menjelaskan mengenai rata-rata deskriptif variabel independen kesesuaian dengan prinsip syariah (X1), rasio leverage $(\mathrm{X} 2)$ rasio revenue recognition (X3) dan Islamic Governance Score (X4). Variabel rasio leverage (X2) dan variabel kesesuaian dengan prinsip syariah (X1) memiliki nilai rata-rata tertinggi yaitu 98,5 dan 98,2. Adapun variabel 
rasio revenue recognition (X3) dan Islamic Governance Score (X4) memiliki nilai rata-rata 31,1 dan 59,7 .

6. Uji Hipotesis

Setelah melalukan uji asumsi klasik dengan kesimpulan bahwa data-data penelitian tidak mengalami bias, selanjutnya peneliti melakukan regresi dengan hasil dari Eviews 9 sebagai berikut :

Dependent Variable: $Y$

Method: Least Squares

Date: 06/12/19 Time: 07:56

Sample (adjusted): 1368

Included observations: 343 after adjustments

\begin{tabular}{|c|c|c|c|c|}
\hline Variable & Coefficient & Std. Error & $\mathrm{t}$-Statistic & Prob. \\
\hline $\mathrm{X} 1$ & 0.250000 & $3.62 \mathrm{E}-16$ & $6.91 \mathrm{E}+14$ & 0.0000 \\
\hline $\mathrm{X} 2$ & 0.250000 & $3.75 \mathrm{E}-16$ & $6.66 \mathrm{E}+14$ & 0.0000 \\
\hline X3 & 0.250000 & $1.14 \mathrm{E}-16$ & $2.20 \mathrm{E}+15$ & 0.0000 \\
\hline$X 4$ & 0.250000 & $2.53 \mathrm{E}-16$ & $9.88 \mathrm{E}+14$ & 0.0000 \\
\hline R-squared & 1.000000 & \multirow{4}{*}{\multicolumn{2}{|c|}{$\begin{array}{l}\text { Mean dependent va } \\
\text { S.D. dependent var } \\
\text { Sum squared resid }\end{array}$}} & r 0.700364 \\
\hline Adjusted R-squared & 1.000000 & & & 0.123536 \\
\hline S.E. of regression & 0.122316 & & & $2.58 \mathrm{E}-28$ \\
\hline Durbin-Watson stat & 1.983611 & & & \\
\hline
\end{tabular}

Sumber : hasil olah data Eviews 9.

Uji koefisien regresi dapat dilihat melalui Prob. t. Apabila nilai prob. t hitung (ditunjukkan pada Prob.) lebih kecil dari tingkat kesalahan (alpha) 0,05 maka dapat dikatakan bahwa variabel independen berpengaruh signifikan terhadap variabel dependennya. Sedangkan apabila nilai prob. $t$ hitung lebih besar dari tingkat kesalahan 0,05 maka dapat dikatakan bahwa variabel independen tidak berpengaruh signifikan terhadap variabel dependennya.

Nilai prob. $\mathrm{t}$ hitung dari variabel kesesuaian dengan prinsip syariah (X1), rasio leverage (X2), rasio revenue recognition (X3) dan Islamic Governance Score (X4) sebesar 0,0000 lebih kecil dari 0,05 sehingga semua variabel independen tersebut berpengaruh signifikan terhadap variabel 
dependen tingkat pengungkapan $(\mathrm{Y})$ pada alpha 5\%. Dengan kata lain, variabel kesesuaian dengan prinsip syariah $(\mathrm{X} 1)$, rasio leverage $(\mathrm{X} 2)$, rasio revenue recognition (X3) dan Islamic Governance Score (X4) berpengaruh signifikan terhadap tingkat pengungkapan pada taraf keyakinan $95 \%$.

Model regresi valid sebagai model prediktor dalam hasil olah data diatas ditunjukkan dengan standar error (S.E of regression) lebih kecil daripada nilai standar deviasi variabel response (S.D dependent var) $0,122316<0,123536$.

\section{SIMPULAN}

Dari seluruh pengujian empiris yang telah dilakukan, maka kesimpulannya sebagai berikut : (1) kesesuaian dengan prinsip syariah menjadi penting dalam meningkatkan nilai perusahaan dalam hal pengungkapan laporan tahunan. (2) Rasio leverage berpengaruh signifikan terhadap tingkat pengungkapan. Hal ini menunjukkan bahwa rasio leverage berperan dalam meningkatkan nilai tambah bagi pengungkapan efek syariah. (3) Rasio revenue recognition menjadi hal penting. Semakin sesuai rasio revenue recognition efek syariah dengan peraturan yang ditetapkan oleh DSN-MUI dan tertulis dalam Peraturan Otoritas Jasa Keuangan (OJK) maka semakin tinggi tingkat pengungkapan pada efek syariah. (4) Islamic governance score juga sangat berpengaruh sebagai bentuk menjaga kredibilitas efek syariah di mata nasabah dan investor yang menginginkan instrumen keuangan syariah.

Beberapa keterbatasan dalam penelitian ini adalah (1) jumlah sampel hanya terbatas pada Daftar Efek Syariah di Negara Indonesia sehingga hal ini tidak menggambarkan kesimpulan secara global pada efek syariah. (2) Pengembangan indeks hanya merujuk pada empat standar pengungkapan yang ditetapkan oleh DSN-MUI dan tertulis dalam Peraturan Otoritas Jasa Keuangan (OJK) sehingga pengungkapan tersebut kurang maksimal. (3) Periode penelitian relatif pendek hanya satu tahun sehingga analisis perkembangan tingkat keluasan pengungkapan kurang mendalam.

Terkait dengan keterbatasan penelitian yang ada, maka penulis memberikan beberapa saran untuk penelitian selanjutnya, yaitu: (1) Menambahkan objek penelitian dari beberapa Negara sehingga dapat menyimpulkan hasil secara mendunia dan menambahkan variabel penelitian sehingga model penelitian lebih berkembang. (2) Menambahkan 
telaah literatur pada indeks pengungkapan dari Negara lain agar indeks pengungkapan bisa digunakan di seluruh dunia. Telaah melalui pendekatan nilai-nilai agama juga dirasa perlu sebagai alasan untuk memperkuat penentuan indeks pengungkapan syariah tersebut juga sebagai cerminan indeks pengungkapan secara umum dan secara syariah. (3) Menambahkan periode penelitian sehingga analisis perkembangan tingkat keluasan pengungkapan lebih mendalam.

\section{DAFTAR RUJUKAN}

AAOIFI. (2015). Shari'ah Standards for Islamic FInancial Institutions. Manama: Worldwide Distribution: Dar AlMaiman for Publishing \& Distributing.

Ahmed, M., \& Khatun, M. (2014). The Compliance with Shariah Governance System of AAOIFI: A Study on Islamic Banks Bangladesh. Journal of Islamic Economics, Banking and Finance, 9(3), 177-191. https://doi.org/10.12816/0001617.

Al-Sulaiti, J., Ousama, A. A., \& Hamammi, H. (2018). The compliance of disclosure with AAOIFI financial accounting standards: A comparison between Bahrain and Qatar Islamic banks. Journal of Islamic Accounting and Business Research, 9(4), 549-566. https://doi.org/10.1108/JIABR-10-2017-0144.

Alessandri, S\&Westcott. (2001). Modeling corporate identity: a concept explication and theoretical explanation. Corporate Communications: An International Journal, 6, 173-182.http://dx.doi.org/10.1108/EUM0000000006146

Che Azmi, Anna. (2016). Journal of Islamic Accounting and Business Research. 7(3), 34-60.http://dx.doi.org/10.1108/JIABR-03-2016-0029

Ardian, N. K., \& Adityawarman. (2015). Pengungkapan Syariah pada Bank Syariah di Indonesia. Diponegoro Journal of Accounting, 4(3), 1-11.

Baharudin, A. (2015). Utang dan Pendapatan Perusahaan dalam Kriteria dan Penerbitan Efek Syariah Perspektif Hukum Bisnis Syariah. Thesis Program Studi Hukum Islam Konsentrasi Hukum Bisnis Syariah, $1-55$.

Budiono, A. (2017). Penerapan prinsip syariah pada lembaga keuangan syariah. 
2(1), 54-65.

Fatin Nabilah, Maslichah, dan Afifudin. (2016). Pengaruh Islamic Governance Score, Leverage, Profitabilitas, Dan Size Terhadap Islamic Social Reporting Index Pada Bank Umum Syariah Di Indonesia Periode 2012-2016. Jurnal Fakultas Ekonomi Universitas Islam Malang, 4(1), 70-84.

Ghozali, Imam. (2007). Aplikasi Analisis Multivariate dengan Program SPSS. Badan Penerbit Universitas Diponegoro, Semarang.

Hadi, Syamsul. (2017). Audit dan Tata Kelola Lembaga Keuangan Syariah. Jurnal Az Zarqa', 9(2), 1-14.

Hafij Ullah Mohammad, A. (2013). Corporate Social Responsibility Reporting Practices in Banking Companies in Bangladesh: Impact of Regulatory Change.Journal of Financial Reporting and Accounting, 8(539).http://dx.doi.org/10.1108/JFRA-05-2013-0038

Halaby, Sherif K H. (2016). International Journal of Islamic and Middle Eastern Finance and Management Article information: Determinants of Compliance with AAOIFI Standards by Islamic Banks. International Journal of Islamic and Middle Eastern Finance and Management,9(1), 1-21.http://dx.doi.org/10.1108/IMEFM-06-2015-0074

Harahap. (2001). Kritik Terhadap PSAK Perbankan Syariah IAI dan AAOIFI. Media Riset Akuntansi, Auditing dan Informasi Vol I No 3pp. 87-105.

Khoiruddin, M., \& Faizati, E. R. (2014). Reaksi Pasar Terhadap Dividend Announcement Perusahaan Yang Sahamnya Masuk Daftar Efek Syariah. Jurnal Dinamika Manajemen, 5(2), 209-219. https://doi.org/10.15294/jdm.v5i2.3662

Malik, M., Malik, A., \& Mustafa, W. (2011). Controversies that make Islamic banking controversial: An analysis of issues and challenges. American Journal of Social and Management Sciences, 41-46. https://doi.org/10.5251/ajsms.2011.2.1.41.46.

Peraturan Bank Indonesia (2011). Pelaksanaan Fungsi Kepatuhan Bank Umum Nomor 13/2/PBI/2011.

Prasetyo Supadi, D. B., \& Amin, M. N. (2017). Pengaruh Faktor 
Fundamental Dan Risiko Sistematis Terhadap Return Saham Syariah. Media Riset Akuntansi, Auditing Dan Informasi, 12(1), 23. https://doi.org/10.25105/mraai.v12i1.581.

Purwanti. (2006). Pengaruh Karakteristik Komite Audit terhadap Ketepatan Waktu Pelaporan Keuangan pada Perusahaan Publik yang Tercatat di BEJ. Tesis Universitas Diponegoro, 6-25.

Ramadhani, Febry. (2016). Pengaruh Ukuran Perusahaan, Profitabilitas, Leverage Dan Ukuran Dewan Pengawas Syariah Terhadap Pengungkapan Islamic Social Reporting (Studi Empiris Pada Bank Umum Syariah di Indonesia Tahun 2010-2014). Jurnal Online Mahasiswa (JOM) Fakultas Ekonomi Universitas Riau, 3(2), 1-46. https://doi.org/http://dx.doi.org/110.21043/equilibrium.v3i2.1268.

Retno M, R. D., \& Priantinah, D. (2012). Pengaruh Good Corporate Governance dan Pengungkapan Corporate Social Responsibility Terhadap Nilai Perusahaan (Studi Empiris Pada Perusahaan. Jurnal Nominal, I(1), 84-103.

Rifqi Muhammad, S. (2015). Landasan Teori Akuntansi Syariah. Landasan Teori Akuntansi Syariah, 1, 1-50. Retrieved from http://www.pustaka.ut.ac.id/lib/wp-content/uploads/pdfmk/EKMA 4482-M1.pdf.

Rita Rosiana, Bustanul Arifin, M. H. (2015). Pengaruh Ukuran Perusahaan, Profitabilitas, Leverage, Dan Islamic Governance Score Terhadap Pengungkapan Islamic Social Reporting (Studi Empiris pada Bank Umum Syariah di Indonesia Tahun 2010-2012). E S E N S I Jurnal Bisnis Dan Manajemen, 5(1), 87-104.

Rizfani, K. N., \& Lubis, D. (2019). Pengungkapan Islamic Social Reporting pada Perusahaan di Jakarta Islamic Index. Jurnal Al-Muzara'ah, 6(2), 103-116. https://doi.org/10.29244/jam.6.2.103-116.

Rostiani, S. S \&Sukanta, T. A. (2018). Pengaruh Dewan Pengawas Syariah, Profitabilitas Dan Leverage Terhadap Pengungkapan Islamic Social Reporting (ISR) (Studi Pada Bank Umum Syariah di Indonesia Periode 2012-2016). Jurnal Akuntansi Bisnis Dan Ekonomi, IV(2).

Septyan, Krisno. (2018). Determinasi Tingkat Pengungkapan Bank Syariah di Beberapa Negara. Jurnal Akuntansi Dan Keuangan Islam, 6(2), 
127-142. https://doi.org/10.5281/jakis.v6i2.11.

Sole, Juan. (2007). Introducing Islamic Banks into Conventional Banking Systems. International Monetary Fund Working Paper 1-28.

Sukardi, Budi. (2012). PRODUK BANK SYARIAH DI INDONESIA. Jurnal IAIN Surakarta, 3(1), 1-17. 